\title{
Hydrothermal Treatments Affecting the Concentration of Neochlorogenic Acid in Dough of Tartary Buckwheat
}

\author{
Mateja Germ ${ }^{1, *}$, Július Árvay ${ }^{2}\left(D\right.$, Alena Vollmannová ${ }^{2}$, Tomáš Tóth ${ }^{2}$, Ivan Kreft ${ }^{3}$ \\ and Aleksandra Golob ${ }^{1}$ \\ 1 Biotechnical Faculty, University of Ljubljana, Jamnikarjeva 101, SI-1000 Ljubljana, Slovenia; \\ aleksandra.golob@bf.uni-lj.si \\ 2 Department of Chemistry, Slovak University of Agriculture, Tr. A. Hlinku 2, SK-94901 Nitra, Slovakia; \\ julius.arvay@uniag.sk (J.Á.); alena.vollmannova@gmail.com (A.V.); tomas.toth@uniag.sk (T.T.) \\ 3 Nutrition Institute, Tržaška cesta 40, SI-1000 Ljubljana, Slovenia; ivan.kreft@guest.arnes.si \\ * Correspondence: mateja.germ@bf.uni-lj.si; Tel.: +386-1-320-3333
}

Received: 27 October 2020; Accepted: 1 December 2020; Published: 3 December 2020

\begin{abstract}
This study investigated the effects of initial temperature treatments of gluten-free doughs made from Tartary buckwheat flour, and time of methanol extraction from the cooked doughs of neochlorogenic acid, an important polyphenol metabolite. The doughs were hydrothermally treated from $25^{\circ} \mathrm{C}$ to $95^{\circ} \mathrm{C}$, cooked at $95^{\circ} \mathrm{C}$ for $20 \mathrm{~min}$, and extracted using $80 \%$ aqueous methanol at the room temperature for $20 \mathrm{~min}, 2 \mathrm{~h}$, and $8 \mathrm{~h}$. For the control, nonhydrothermally treated Tartary buckwheat flour samples, the extractable neochlorogenic acid was similar for these extraction times. For the cooked dough samples, the hydrothermal treatments were important in terms of extractability of neochlorogenic acid. The extractable neochlorogenic acid was higher for the control samples in comparison to the hydrothermally treated and cooked dough samples. Among these hydrothermally treated dough samples, the high extractable neochlorogenic acid concentrations were maintained for temperatures of at least $80^{\circ} \mathrm{C}$. These high-temperature initial treatments during dough preparation appear to prevent degradation of the neochlorogenic acid in Tartary buckwheat flour. During hydrothermal treatment, neochlorogenic acid is bound to grain structures in such a way that prolonged extraction time is needed to extract it.
\end{abstract}

Keywords: hydrothermal treatment; neochlorogenic acid; buckwheat dough; Tartary buckwheat (Fagopyrum tataricum)

\section{Introduction}

Due to important effects on human health, Tartary buckwheat (Fagopyrum tataricum) is recently widespread in the preparation of various gluten-free foods [1]. It is cultivated or was recently cultivated in the mountains of south-west China, and in Nepal, northern India, Bhutan, Luxemburg, Slovenia, Italy, Sweden, and Bosnia and Herzegovina [2-4]. The high attention in common buckwheat and Tartary buckwheat breeding was given to reach high yields of grain in different ecological and agricultural environments. Much care has been given on the breeding, to facilitate husking and ensure nice taste [5]. Buckwheat is an annually growing plant rich in flavonoids, especially rutin. In the study by Dziedzic et al. [6], they found out that in Tartary buckwheat, among the investigated polyphenolic substances the contents of rutin and chlorogenic acid were the highest. Other polyphenolic substances, determined in Tartary buckwheat were: 2,6-dihydroxybenzoic acid, 3,4-dihydroxybenzoic acid, 3,5-dihydroxybenzoic acid, 4-hydrobenzoic acid, caffeic acid, catechin, chlorogenic acid, fagopyrin, ferulic acid, myricetin, gallic acid, isovanilic acid, isovitexin, kaempferol, luteolin, p-coumaric acid, 
procyanidin B2, quercetin, quercetin 3-D galactoside, rutin, syringic acid, and vitexin. Since this characteristic is an important factor in the usefulness of the plant for the pharmaceutical industry, buckwheat herb is therefore included in European Pharmacopoeia [7]. Whole buckwheat contains 2-5 times more phenolic compounds than barley and oats, while buckwheat bran and hulls have 2-7 times higher antioxidant activity than barley, triticale, and oats [8]. Buckwheat plants contain three classes of flavonoids: flavonols, anthocyanins and C-glucosyl flavones, which have been attributed beneficial properties as food constituents [6]. Buckwheat flour can be used in making gluten free food products, such as cakes, bread, wafers, and even tulumba dessert [9-13]. Gluten free products are very important in the diet of people with celiac disease [14]. Tartary buckwheat contains phenolic compounds that are reported to have anti-inflammatory, anticancer, antithrombotic and antioxidant activity [15-19], whereby the overall antioxidative activity of Tartary buckwheat will depend on the combination of the identified phenolics and the unidentified (minor) components. Phenolic compounds have variety of roles in plant life ranging from structural to protection $[20,21]$. They consist of an aromatic ring with one or more hydroxyl groups [21]. Robbins [21] stated that plant phenolic acids are divided into two groups: hydroxycinnamic acids and hydroxybenzoic acids. An important conjugated phenolic acid described is the chlorogenic acid (3-O-caffeoylquinic acid, CQA) which is essentially ubiquitous in the plant kingdom [22,23]. Clifford [22] reported in his paper that many of biological effects has been assigned to C-QA that attributed it into a popular compound, which has been often reported as a health promoting agent.

Neochlorogenic acid (Figure 1) is the ester formed by caffeic acid and (-)-quinic acid, and it functions as an intermediate in lignin biosynthesis. It is found in some types of dried fruit and a variety of other plant sources, such as peaches and herbs. According to Noratto et al. [24], neochlorogenic and chlorogenic acids have potential as chemopreventive dietary compounds, because they have shown relatively high growth inhibition on an estrogen-independent breast cancer cell line and on the other hand low toxicity against normal cells. In fact, neochlorogenic acid might be a colon cancer suppressive component of prunes [25].<smiles>O=C(/C=C/c1ccc(O)c(O)c1)O[C@@H]1C[C@@](O)(C(=O)O)C[C@H](O)[C@H]1O</smiles>

Figure 1. The structure of neochlorogenic acid (5-O-caffeoylquinic acid), an isomer of chlorogenic acid and a natural polyphenolic compound.

For Tartary buckwheat, Vogrinčič et al. [26] investigated the protective effects against DNA damage of complex mixtures of polyphenols, together with the other constituents that are present in whole plant material. Here, there were greater benefits for these complex mixtures than for the pure individual metabolites alone. Based on this, there is a need for further research into the activities of these and other compounds in Tartary buckwheat extracts. Although these are not as abundant as the main flavonoids, they have potential synergistic effects or can have significant contributions toward antigenotoxic properties. Thus, Vogrinčič et al. [26] suggested that Tartary buckwheat can be recommended to be included in the diet more often. Kurita et al. [27] reported about the identification of the predominant antioxidant compound in Polygonum cuspidatum, which belongs to the same family as Fagopyrum tataricum. The main active compound in the methanol extract of fresh samples was identified as neochlorogenic acid. Given the reports of health-promoting effects of neochlorogenic acid, their result may increase the utility of P. cuspidatum. 
Hydrothermal treatments comprise heating with hot water or also steam, followed by slow cooling and drying. Such hydrothermal treatments are used with buckwheat to produce buckwheat groats, according to traditional technologies in Slovenia, Croatia, Czech Republic, Slovakia, Poland, Ukraine, and Russia [28]. The purpose of this study was to define the impact of temperature in Tartary buckwheat dough preparation on the concentration of extractable neochlorogenic acid.

\section{Materials and Methods}

\subsection{Plant Material and Chemicals}

Cv. Zlata Tartary buckwheat flour was received from Rangus Mill (Dolenje Vrhpolje, Šentjernej, Slovenia). The neochlorogenic acid standard ((1R,3R,4S,5R)-3-\{[(2E)-3-(3,4-Dihydroxyphenyl)prop-2-enoyl]oxy\}1,4,5-trihydroxycyclohexanecarboxylic acid), methanol $\left(\mathrm{CH}_{3} \mathrm{CH}_{2} \mathrm{OH}, \mathrm{HPLC}\right.$ grade), acetonitrile $\left(\mathrm{CH}_{3} \mathrm{CN}\right.$, gradient HPLC grade), and orthophosphoric acid $\left(\mathrm{H}_{3} \mathrm{PO}_{4}, \mathrm{ACS}\right.$ grade) were obtained from Sigma-Aldrich (Steiheim, Germany). Double deionized water $\left(\mathrm{ddH}_{2} \mathrm{O}\right)$ was produced using a water purification system (Simplicity 185; Millipore SAS, Molsheim, France), to an electrical resistance of $0.054 \mu \mathrm{S} \mathrm{cm}{ }^{-1}$.

\subsection{Determination of Neochlorogenic Acid}

A standard solution of neochlorogenic acid was prepared by dissolving $0.5 \mathrm{mg}$ neochlorogenic acid in $10 \mathrm{~mL}$ methanol. The lyophilized cooked dough samples $(2 \mathrm{~g})$ were homogenized using a pestle and mortar and then extracted with $20 \mathrm{~mL} 80 \%$ aqueous methanol $(v / v)$ at room temperature for $20 \mathrm{~min}, 2 \mathrm{~h}$ and $8 \mathrm{~h}$, with shaking on a shaker (horizontal, $250 \mathrm{rpm}$ ). The methanol extracts were then filtered (Munktell No 390 paper; Munktell \& Filtrac, GmbH, Bärenstein, Germany) and closed and stored in plastic 20-mL tubes. Prior to injection into the HPLC system (see below), the extracts and standard solutions were cleaned by filtering through syringe filters (Q-Max, $25 \mathrm{~mm}, 0.22 \mu \mathrm{m}$; Frisenette ApS, Knebel, Denmark).

The neochlorogenic acid concentrations in the cooked dough samples and control flour were determined using a high performance liquid chromatography system (1260 Infinity; Agilent Technologies, Waldbronn, Germany) with a quarternary solvent manager coupled to a degasser (Cat $\mathrm{N}^{\circ}$ G1311B), sample manager (Cat $\mathrm{N}^{\circ}$ G1329B), column manager (Cat $\mathrm{N}^{\circ}$ G1316A) and diode array detector (Cat $\mathrm{N}^{\circ}$ G1315C; all from Agilent Technologies). All of the HPLC analyses were performed on a reverse phase C18 column Purosphere ${ }^{\circledR} 4 \mathrm{~mm} \times 250 \mathrm{~mm} \times 5 \mu \mathrm{m}$ (Merck, KGaA, Darmstadt, Germany).

The mobile phase for the HPLC analyses was comprised of acetonitrile (A) and $0.1 \%$ orthophosphoric acid in $\mathrm{ddH}_{2} \mathrm{O}$ (B). The gradient of elution was following: $0 \rightarrow 1 \mathrm{~min}, 20 \% \mathrm{~A}$; $1 \rightarrow 5 \mathrm{~min} 20 \% \rightarrow 25 \%$ A; $5 \rightarrow 15 \mathrm{~min}, 25 \% \rightarrow 30 \%$ A; $15-25 \mathrm{~min}, 30 \% \rightarrow 40 \%$ A. The injection volume was $10 \mu \mathrm{L}$ and the flow rate $1 \mathrm{~mL} \mathrm{~min}^{-1}$. The temperature of the column oven was adjusted to $30^{\circ} \mathrm{C}$, the samples were kept in the sample manager at $6^{\circ} \mathrm{C}$. The detection wavelength was $320 \mathrm{~nm}$. The results were collected and processed further using the OpenLab ChemStation software for LC 3D systems (Agilent Technologies). The limit of detection for neochlorogenic acid was $1.06 \mathrm{mg} \mathrm{kg}^{-1}$ sample, and the limit of quantification was $3.50 \mathrm{mg} \mathrm{kg}^{-1}$ sample.

\subsection{Hydrothermal Treatments}

Flour (100 g) containing $8 \%$ moisture was mixed for 1 min with $200 \mathrm{~g}$ water at $25^{\circ} \mathrm{C}, 45^{\circ} \mathrm{C}, 60^{\circ} \mathrm{C}$, $80^{\circ} \mathrm{C}$, or $95^{\circ} \mathrm{C}$ (TurboFixx $400 \mathrm{~W}$, speed 3; Robert Bosch GmbH, Gerlingen-Schillerhöhe, Germany). The resulting doughs were kept in a chamber for $20 \mathrm{~min}$ at their respective temperatures. After this treatment, each dough sample was heated to $95{ }^{\circ} \mathrm{C}$ for additional $20 \mathrm{~min}$. After the dough samples were cooled to room temperature, they were frozen $\left(-18^{\circ} \mathrm{C}\right)$ until they were lyophilized. The complete procedures were performed independently as three repetitions. The samples were freeze-dried, milled and used in the methanol extractions for HPLC analyses. Chromatograms for the samples analyzed were for control flour and for all mixtures with water presented in the way as it is shown as examples in Figures 2-6. 


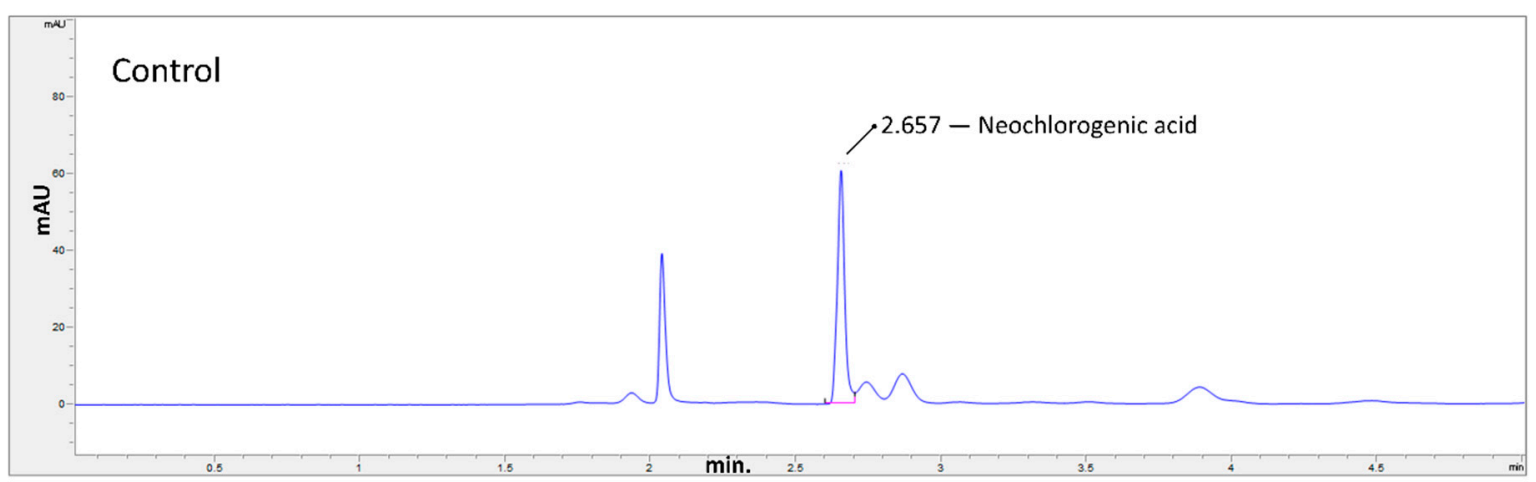

Figure 2. The chromatogram of neochlorogenic acid result in control flour, after $8 \mathrm{~h}$ of extraction.

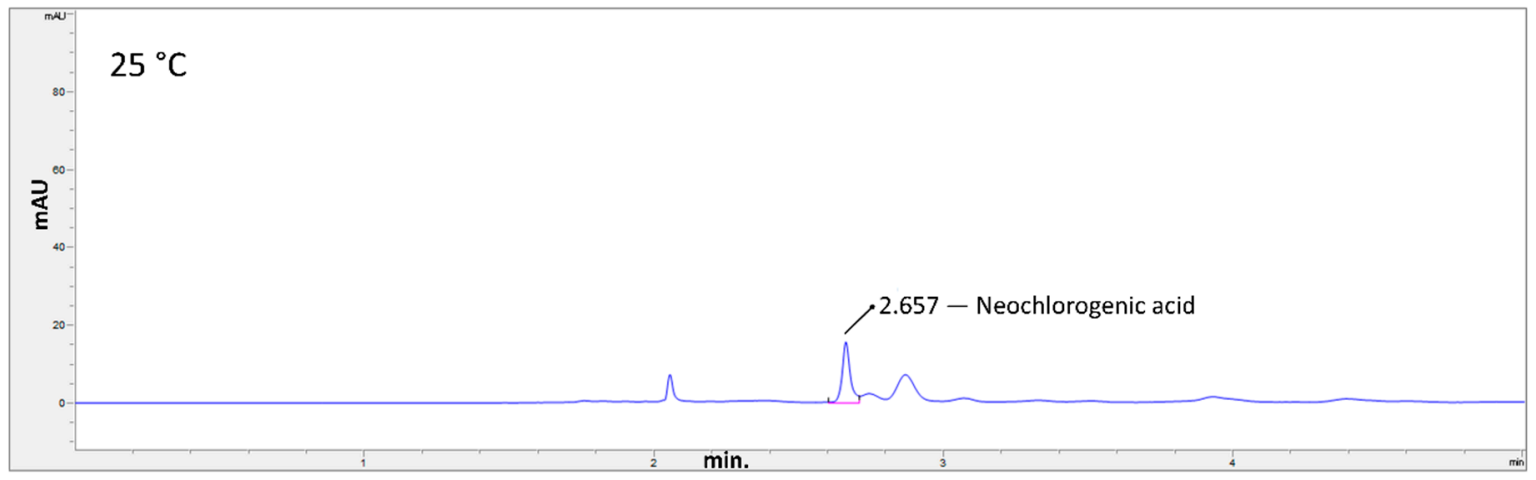

Figure 3. The chromatogram of neochlorogenic acid result for the water-flour mixture at $25^{\circ} \mathrm{C}$, after $8 \mathrm{~h}$ of extraction.

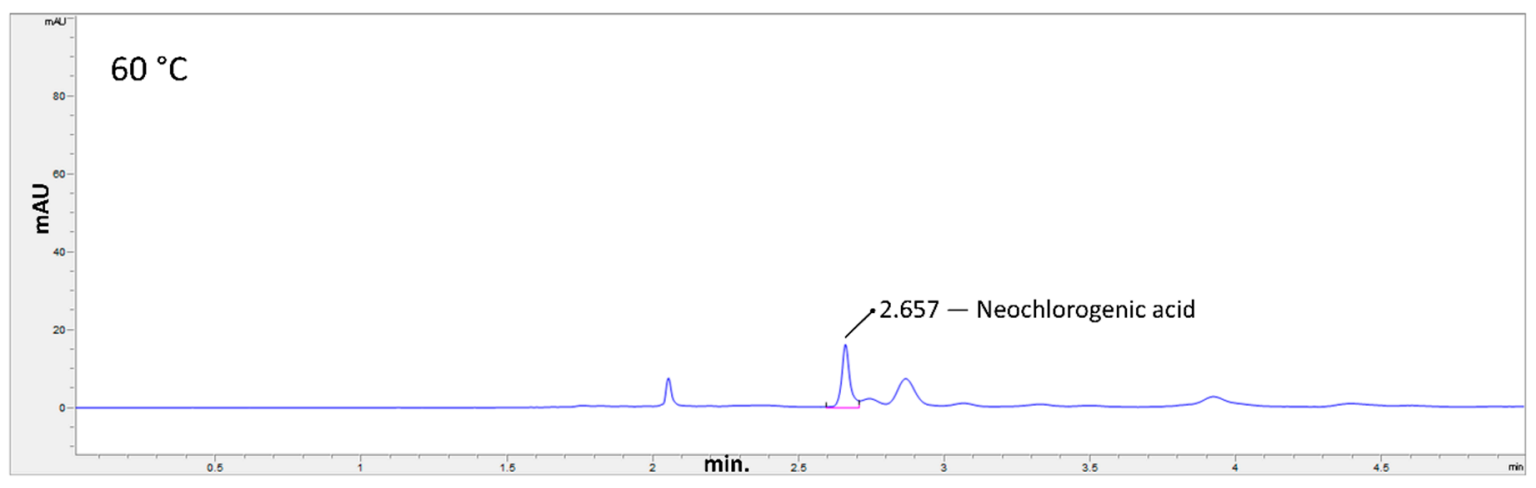

Figure 4. The chromatogram of neochlorogenic acid result for the water-flour mixture at $60{ }^{\circ} \mathrm{C}$, after $8 \mathrm{~h}$ of extraction.

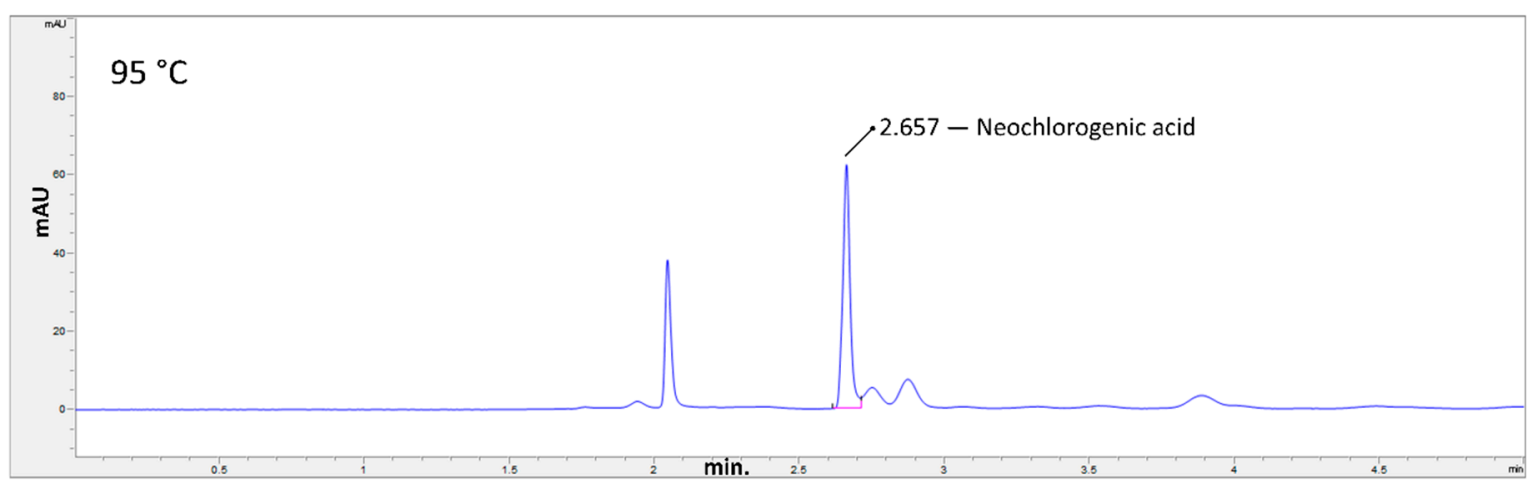

Figure 5. The chromatogram of neochlorogenic acid result for the water-flour mixture at $95^{\circ} \mathrm{C}$, after $8 \mathrm{~h}$ of extraction. 


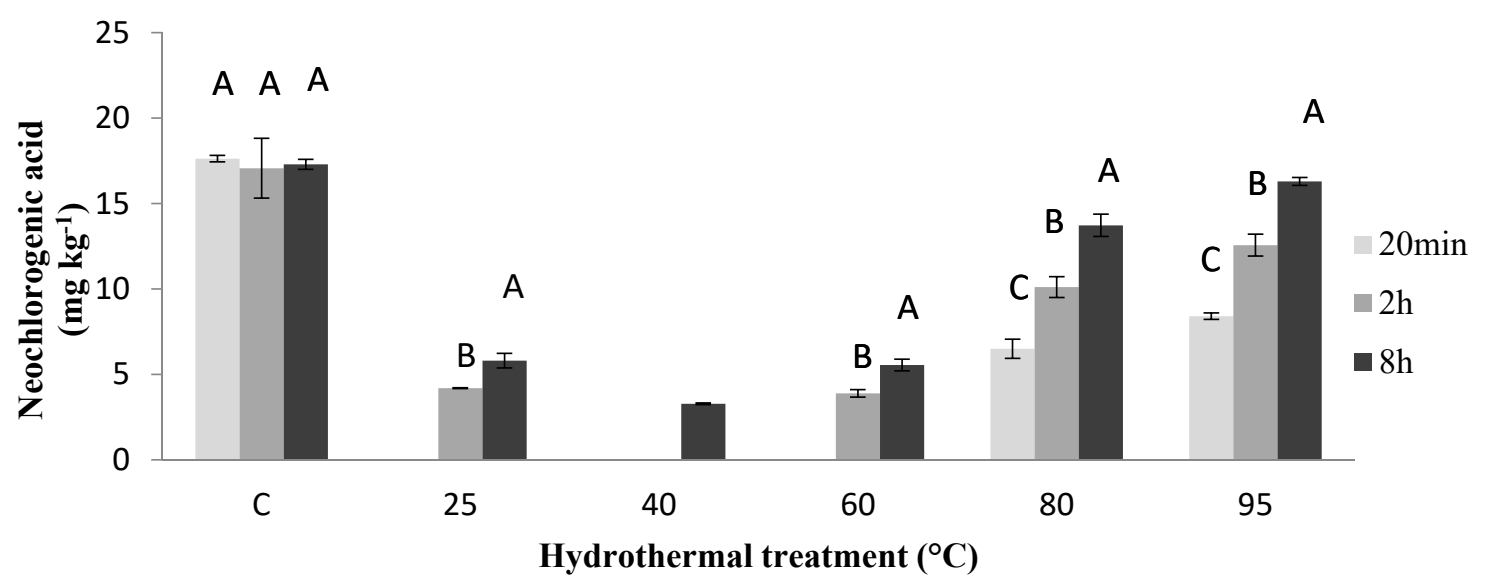

Figure 6. Time-courses of neochlorogenic acid extraction (mg neochlorogenic acid $\cdot \mathrm{kg}^{-1} \mathrm{dry}$ matter) with 20\% (v/v) aqueous methanol for Tartary buckwheat flour (C; control) and following cooking $\left(95^{\circ} \mathrm{C}\right.$, $20 \mathrm{~min})$ of the hydrothermally treated $\left(25,45,60,80,95^{\circ} \mathrm{C}\right)$ Tartary buckwheat dough samples. Results are means \pm standard deviation $(n=3)$, except for treatments where neochlorogenic acid was under the limit of detection. Different letters above the columns $(\mathrm{A}, \mathrm{B}, \mathrm{C})$, indicate statistically significant differences between the extraction times within control (flour), respectively within each temperature condition $(p<0.05)$.

\subsection{Statistical Analysis}

The results are given as means \pm standard deviation from three independently processed samples. ANOVA was performed, followed by Tukey post-hoc tests (for controls and hydrothermally treated samples at $80^{\circ} \mathrm{C}$ and $95^{\circ} \mathrm{C}$ ), or Student's t-tests (for hydrothermally treated samples at $25^{\circ} \mathrm{C}, 40^{\circ} \mathrm{C}$ and $60^{\circ} \mathrm{C}$ ). The results were considered as significantly different at $p<0.05$.

\section{Results and Discussion}

The extractability of neochlorogenic acid using $80 \%$ aqueous methanol from the control Tartary buckwheat flour samples and following the cooking $\left(95^{\circ} \mathrm{C}, 20 \mathrm{~min}\right)$ of the hydrothermally treated $\left(25,45,60,80,95^{\circ} \mathrm{C}\right)$ Tartary buckwheat dough samples are illustrated in Figure 6 . In the controls, all of the extractable neochlorogenic acid was extracted within the first $20 \mathrm{~min}$, which remained similar after the extraction times of $2 \mathrm{~h}$ and $8 \mathrm{~h}$. Thus, the neochlorogenic acid was easily extractable from the untreated Tartary buckwheat flour with $80 \% v / v$ aqueous methanol.

During the hydrothermal treatments of the doughs at 25,40 , and $60^{\circ} \mathrm{C}$, the neochlorogenic acid extracted from the cooked doughs using $20 \%$ aqueous methanol was lower than for the control samples (at about 30\%; Figure 6). Moreover, after all of the dough hydrothermal treatments (i.e., 25, 40, 60, 80, $95^{\circ} \mathrm{C}$ ), the concentrations of neochlorogenic acid extracted from the cooked doughs were dependent on the times of extraction. Indeed, in the dough samples that had been hydrothermally treated at 25 , 40 and $60{ }^{\circ} \mathrm{C}$, no neochlorogenic acid was extracted from the cooked doughs after $20 \mathrm{~min}$, indicating that compared to the flour controls, the extraction of neochlorogenic acid from these cooked doughs requires a relatively longer time. Hydrothermal treatment at $25^{\circ} \mathrm{C}, 40{ }^{\circ} \mathrm{C}$ and $60{ }^{\circ} \mathrm{C}$ affected the degradation process of neochlorogenic acid only partly. So, some neochlorogenic acid persisted in the dough after treatment at $25^{\circ} \mathrm{C}, 40^{\circ} \mathrm{C}$ and $60^{\circ} \mathrm{C}$, up to the $8 \mathrm{~h}$ extraction.

For these hydrothermal treatments at 25,40 , and $60^{\circ} \mathrm{C}$ where there was relatively little extraction of neochlorogenic acid, two processes might be involved that would account for this lower extractability. In one scenario, neochlorogenic acid might be degraded by the enzymes in the Tartary buckwheat doughs, which would be functional during the hydrothermal treatments at 25,40 , and $60^{\circ} \mathrm{C}$, but not during the hydrothermal treatments at 80 and $95^{\circ} \mathrm{C}$. Alternatively, at the lower temperatures of the doughs, the neochlorogenic acid might form insoluble complexes. Here, while these low concentrations of neochlorogenic acid extracted from the cooked doughs might support the first process, the delayed 
extraction of neochlorogenic acid across all of the hydrothermal treatments used would support the second process. However, at this stage, it can only be said that both types of metabolic events might be involved.

It is also interesting that the highest concentrations of neochlorogenic acid extracted were from the control flour after $20 \mathrm{~min}$ and $2 \mathrm{~h}$ of extraction, while after $8 \mathrm{~h}$ of extraction, the neochlorogenic acid extracted was similar in the control and $95{ }^{\circ} \mathrm{C}$ hydrothermally treated dough samples (Figure 6). Dawidowidz and Typek [29] identified 14 compounds (i.e., chlorogenic acid derivatives and its hydrolysis products) that were formed from 5-O-caffeoylquinic acid by heating its aqueous solutions at different $\mathrm{pHs}$. The levels of the components formed depended on the heating times and the $\mathrm{pH}$. Moreover, data from Dawidowidz and Typek [30] showed that high temperature cooking of blueberries caused 5-O-caffeoylquinic acid transformation and isomerization, with 11 compounds formed from 5-O-caffeoylquinic acid during the treatment of blueberries.

Apart from the controls, the highest concentrations of neochlorogenic acid extracted here were from the dough treated at $95^{\circ} \mathrm{C}$ by 'scalding' the Tartary buckwheat flour and maintaining the dough formed at the same temperature for $20 \mathrm{~min}$, followed by cooking $\left(95^{\circ} \mathrm{C}\right.$ for $\left.20 \mathrm{~min}\right)$. However, the efficient extraction of neochlorogenic acid from these samples using $20 \%$ aqueous methanol required $8 \mathrm{~h}$ of extraction. This indicates that during the high-temperature treatment of the dough, slowly extractable complexes of neochlorogenic acid appear to have been formed. It is possible that neochlorogenic acid formed complexes with amylose, or with some of the other components of the Tartary buckwheat flour; however, this remains to be determined through further studies.

\section{Conclusions}

In nonhydrothermally treated Tartary buckwheat flour samples, extraction of neochlorogenic acid with $80 \%$ aqueous methanol was complete within $20 \mathrm{~min}$ of extraction. The hydrothermal treatments of the dough samples were important for the extractability of neochlorogenic acid from the cooked doughs. For successful extraction of neochlorogenic acid from these cooked doughs, at least a prior $80^{\circ} \mathrm{C}$ or more hydrothermal treatment of the dough and an $8 \mathrm{~h}$ extraction with $80 \%$ aqueous methanol are needed. These data thus indicate that high temperature $\left(>80^{\circ} \mathrm{C}\right)$ hydrothermal treatment is needed for Tartary buckwheat flour during dough preparation to preserve the valuable extractable neochlorogenic acid in such Tartary buckwheat food products. Hydrothermal treatment is a part of procedure for making Tartary buckwheat food products and foods. During this treatment small molecules, like neochlorogenic acid, leave their original place and with the water flow they enter into starch grains and other grain structures. Therefore, for extraction medium $(20 \%(v / v)$ aqueous methanol), it takes a longer time to dissolve neochlorogenic acid from starch and other grain structures.

Author Contributions: Conceptualization: I.K., Methodology: J.Á., Formal analysis and investigation: A.V., T.T., Writing_original draft preparation: A.G., M.G., Writing—review and editing: I.K., M.G., A.G. All authors have read and agreed to the published version of the manuscript.

Funding: This research was funded by the Slovenian Research Agency, through programmes "Biology of Plants" (P1-0212) and P3-0395 "Nutrition and Public Health", and projects L4-7552, J7-9398 and L4-9305. The research leading to these studies was funded by the European Community under project SUBTENO 313011T465: Support for research activities in the ABT research center.

Acknowledgments: Authors are thankful for revising the English text to Christopher Berrie.

Conflicts of Interest: The authors declaring no conflict of interest. It was no role of the funders in designing of the study; in collecting, analyzing, or interpreting of results; in the writing of the paper, or in the decision to publish the results. 


\section{References}

1. Kreft, M. Buckwheat phenolic metabolites in health and disease. Nutr. Res. Rev. 2016, 29, 30-39. [CrossRef] [PubMed]

2. Bonafaccia, G.; Gambelli, L.; Fabjan, N.; Kreft, I. Trace elements in flour and bran from common and Tartary buckwheat. Food Chem. 2003, 83, 1-5. [CrossRef]

3. Bonafaccia, G.; Marocchini, M.; Kreft, I. Composition and technological properties of the flour and bran from common and Tartary buckwheat. Food Chem. 2003, 80, 9-15. [CrossRef]

4. Capraro, J.; Magni, C.; Giorgi, A.; Duranti, M.; Scarafoni, A. Comparative 1d- and 2d-electrophoretic protein profiles of ancestral and modern buckwheat seeds grown in the Italian alpine region. Ital. J. Food Sci. 2018, 30, 497-503.

5. Kreft, I.; Zhou, M.; Golob, A.; Germ, M.; Likar, M.; Dziedzic, K.; Luthar, Z. Breeding buckwheat for nutritional quality. Breed. Sci. 2020, 70, 67-73. [CrossRef]

6. Dziedzic, K.; Górecka, D.; Szwengiel, A.; Sulewska, H.; Kreft, I.; Gujska, E.; Walkowiak, J. The Content of Dietary Fibre and Polyphenols in Morphological Parts of Buckwheat (Fagopyrum tataricum). Plant Food Hum. Nutr. 2018, 73, 82-88. [CrossRef]

7. Žvikas, V.; Pukelevičienè, V.; Ivanauskas, L.; Romanovskaja, D.; Jakštas, V. Evaluation of phenolic antioxidant content in organically and conventionally grown buckwheat herb crop and its regrowth. J. Sci. Food Agric. 2017, 97, 3278-3283. [CrossRef]

8. Inglett, G.E.; Rose, D.J.; Chen, D.; Stevenson, D.G.; Biswas, A. Phenolic content and antioxidant activity of extracts from whole buckwheat (Fagopyrum esculentum Moench) with or without microwave rradiation. Food Chem. 2010, 119, 1216-1219. [CrossRef]

9. Costantini, L.; Lukšič, L.; Molinari, R.; Kreft, I.; Bonafaccia, G.; Manzi, L.; Merendino, N. Development of gluten-free bread using tartary buckwheat and chia flour rich in flavonoids and omega-3 fatty acids as ingredients. Food Chem. 2014, 165, 2-240. [CrossRef]

10. Yildiz, O.; Bulut, B. Optimisation of gluten-free tulumba dessert with buckwheat flour and potato starch. Qual. Assur. Saf. Crop. 2016, 8, 117-128. [CrossRef]

11. Unal, H.; Izli, G.; Izli, N.; Asik, B.B. Comparison of some physical and chemical characteristics of buckwheat (Fagopyrum esculentum Moench) grains. CYTA J. Food 2017, 15, 257-265. [CrossRef]

12. Jin, H.R.; Yu, J.; Choi, S.J. Hydrothermal Treatment Enhances Antioxidant Activity and Intestinal Absorption of Rutin in Tartary Buckwheat Flour Extracts. Foods 2020, 9, 8. [CrossRef] [PubMed]

13. Sun, X.; Li, W.; Hu, Y.; Zhou, X.; Ji, M.; Yu, D.; Fujita, K.; Tatsumi, E.; Luan, G. Comparison of pregelatinization methods on physicochemical, functional and structural properties of tartary buckwheat flour and noodle quality. J. Cereal Sci. 2018, 80, 63-71. [CrossRef]

14. Azarbad, H.R.; Mostafa, M.T.; Rashidi, H. Optimization of Gluten-Free Bread Formulation Using Sorghum, Rice, and Millet Flour by D-Optimal Mixture Design Approach. J. Agric. Sci. Tech. 2019, 74, E140-E146. [CrossRef]

15. Holasova, M.; Fiedlerova, V.; Smrcinova, H.; Orsak, M.; Lachman, J.; Vavreinova, S. Buckwheat-The source of antioxidant activity in functional foods. Food Res. Int. 2002, 35, 207-211. [CrossRef]

16. Fabjan, N.; Rode, J.; Košir, I.J.; Wang, Z.; Zhang, Z.; Kreft, I. Tartary buckwheat (Fagopyrum tataricum Gaertn.) as a source of dietary rutin and quercitrin. J. Agric. Food Chem. 2003, 51, 6452-6455. [CrossRef]

17. Kim, S.J.; Zaidul, I.S.M.; Suzuki, T.; Mukasa, Y.; Hashimoto, N.; Takigawa, S.; Noda, T.; Matsuura-Endo, C.; Yamauchi, H. Comparison of phenolic compositions between common and Tartary buckwheat (Fagopyrum) sprouts. Food Chem. 2008, 110, 814-820. [CrossRef]

18. Brunori, A.; Nobili, C.; Procacci, S. Toward the Use of Buckwheat as an Ingredient for the Preparation of Functional Food Molecular Breeding and Nutritional Aspects of Buckwheat. In Molecular Breeding and Nutritional Aspects of Buckwheat; Zhou, M., Kreft, I., Woo, S.H., Chrungoo, N., Wislander, G., Eds.; Elsevier Inc.: Amsterdam, The Netherlands, 2016; pp. 219-225.

19. Zhao, J.; Zhong, L.; Zou, L.; Zhang, C.; Peng, L.; Xiao, W.; Zhao, G. Efficient Promotion of the Sprout Growth and Rutin Production of Tartary Buckwheat by Associated Fungal Endophytes. Cereal Res. Commun. 2014, 42, 401-412. [CrossRef] 
20. Vollmer, M.; Schröter, D.; Esders, S.; Neugart, S.; Farquharson, F.M.; Duncan, S.H.; Schreiner, M.; Louis, P.; Maul, R.; Rohn, S. Chlorogenic acid versus amaranth's caffeoylisocitric acid-Gut microbial degradation of caffeic acid derivatives. Food Res. Int. 2017, 100, 375-384. [CrossRef]

21. Robbins, R.J. Phenolic acids in foods: An overview of analytical methodology. J. Agric. Food Chem. 2003, 51, 2866-2887. [CrossRef]

22. Clifford, M.N. Chlorogenic acids and other cinnamates-Nature, occurrence and dietary burden. J. Sci. Food Agric. 1999, 79, 362-372. [CrossRef]

23. Khanam, U.K.S.; Oba, S.; Yanase, E.; Murakami, Y. Phenolic acids, flavonoids and total antioxidant capacity of selected leafy vegetables. J. Funct. Food 2012, 4, 979-987. [CrossRef]

24. Noratto, G.; Porter, W.; Byrne, D.; Cisneros-Zevallos, L. Identifying peach and plum polyphenols with chemopreventive potential against estrogen-independent breast cancer cells. J. Agric. Food Chem. 2009, 57, 5219-5226. [CrossRef] [PubMed]

25. Thurow, T. Effect of Chlorogenic Acid and Neochlorogenic Acid on Human Colon Cancer Cells. Food Science Undergraduate Honors Theses, University of Arkansas, Fayetteville, NC, USA, 2012.

26. Vogrinčič, M.; Kreft, I.; Filipič, M.; Žegura, B. Antigenotoxic effect of Tartary (Fagopyrum tataricum) and common (Fagopyrum esculentum) buckwheat flour. J. Med. Food 2013, 16, 944-952. [CrossRef]

27. Kurita, S.; Kashiwagi, T.; Ebisu, T.; Shimamura, T.; Ukeda, H. Identification of neochlorogenic acid as the predominant antioxidant in Polygonum cuspidatum leaves. Ital. J. Food Sci. 2016, 28, 25-31. [CrossRef]

28. Kreft, I. Buckwheat in Slovenia. In Ethnobotany of Buckwheat; Kreft, I., Chang, K., Choi, Y.S., Park, C.H., Eds.; Jinsol Publishing Co: Seoul, Korea, 2003; pp. 71-79.

29. Dawidowidz, A.; Typek, R. The influence of $\mathrm{pH}$ on the thermal stability of 5-O-caffeoylquinic acids in aqueous solutions. Eur. Food Res. Technol. 2011, 233, 223-232. [CrossRef]

30. Dawidowidz, A.L.; Typek, R. Transformation of $5 \mathrm{O}$ caffeoylquinic acid in blueberries during high-temperature processing. J. Agric. Food Chem. 2014, 62, 10889-10895. [CrossRef]

Publisher's Note: MDPI stays neutral with regard to jurisdictional claims in published maps and institutional affiliations.

(C) 2020 by the authors. Licensee MDPI, Basel, Switzerland. This article is an open access article distributed under the terms and conditions of the Creative Commons Attribution (CC BY) license (http://creativecommons.org/licenses/by/4.0/). 